NOMENCLATURE

Edited by Gerry Moore, James Lendemer \& Erin Tripp

\title{
The sad story of Agaricus rhacodes/rachodes: Why would an orthographical error with limited current use become accepted through conservation?
}

\author{
Luc Demoulin' \& Vincent Demoulin² \\ 1 Département des Sciences de l'Antiquité, B.Al, Université de Liège, 4000 Liège I, Belgium \\ 2 Institut de Botanique, B.22, Université de Liège, 4000 Liège I, Belgium \\ Author for correspondence: Vincent Demoulin,V.Demoulin@ulg.ac.be
}

\begin{abstract}
The spelling rachodes used by Vittadini in 1833 for a new species of Agaricus has often been considered a correctable orthographical error for rhacodes. Use of the original spelling has however been occasional and was recently promoted by Vellinga and coworkers. The arguments used to support this practice, especially developed by Vellinga and Pennycook, when proposing conservation of rachodes in 2010 are refuted. It is shown that it is philologically illogical to assume an adjective rachodes could have been created, while the existing rhacodes was obviously meant. The use of the two spellings presented by Vellinga and Pennycook is shown to be incomplete. The conclusion is that rachodes should be corrected under Art. 60.1 to rhacodes, the spelling used for every other organism with that epithet, and that this correction is far more universal, including outside Europe, than the usage claimed for justifying a conservation of rachodes. The expenditure of energy caused by the Vellinga and Pennycook proposal shows that new ways to handle orthography of scientific names should be explored.
\end{abstract}

Keywords Code Art. 60; Greek to Latin transliteration; orthography of scientific names

Received: 6 Mar. 2012; revision received: 25 June 2013; accepted: 28 June 2013. DOI: http://dx.doi.org/10.12705/625.2

\section{INTRODUCTION}

Vittadini (1832-1835) published in 1833 a new species of mushroom (nowadays placed in either Lepiota (Pers.) Gray, Macrolepiota Sing. or Chlorophyllum Murrill) with the spelling Agaricus rachodes. Since Fries's correction in 1849, the epithet was commonly spelled "rhacodes". The necessity of this correction is obvious to people familiar with classical languages, for there is no other logical origin for the word than the Greek classical adjective $\rho \alpha \kappa \omega ́ \delta \eta \varsigma$. This was for example clearly stated by Cetto in one of the largest iconographies of Italian fungi (1972: 129): "Da rhakos (gr.) = straccio. Per la pellicola lacerata."

If well attested, the adjective rhacodes is nonetheless not known to everybody since it may be absent from abridged dictionaries. Nonetheless, by 1900 rhacodes was overwhelmingly accepted, what is not as evident as it should be from the tables presented by Vellinga \& Pennycook (2010a) as we will see below. This paper tried to justify the position of De Kok \& Vellinga (1998), Vellinga (2001) and subsequent papers by Vellinga. Those papers used Vittadini's original spelling for the reason that he was consistent in that spelling. Some authors followed, but others resisted, like in the Index Fungorum and the important British checklist (Legon \& Henrici, 2005), which clearly stated rachodes was considered a correctable error.

Vellinga \& Pennycook, proposed to conserve the original spelling (2010b). When this proposal came for review by the Committee for Fungi it immediately became a contentious issue. After a first clear rejection, the second vote that was reported was 7-7 (Norvell, 2011) and the issue was referred to the General Committee. The secretary of the General Committee returned the issue to the Committee for Fungi, which took a new vote, this time favourable to the proposal. This change of attitude was due to a memo sent in July by J. Melot for review before the third vote was taken.

This issue did cost a disproportionate expenditure of time and energy to several people. It thus was thought it should be the object of a paper illustrating some of the problems with the orthographical section of the Code (Art. 60). It may thus help reinitiate some progress in trying to make this article as useful as possible.

\section{WHAT ARE THE POSSIBLE REASONS FOR THE SPELLING RACHODES AND SHOULD IT BE CORRECTED?}

When one reads the original description and gets correct information on relevant existing Greek words and their derivatives in other languages, it is obvious rachodes is a slip of the pen for rhacodes and should be corrected.

To understand this, one must first be reminded of rules of transliteration of classical Greek into Latin. This has a long history, but even if some variations can occur if one makes the 
distinction between transliteration and transcription, the aspirate consonants $\varphi, \chi, \vartheta$ are always transliterated $\mathrm{ph}, \mathrm{ch}$, th and initial $\rho$, rh (Verbrugghe, 1999). According to the same author, kappa should be transliterated to $\mathrm{k}$. This is convenient but the classical tradition is to transliterate to c (Biville, 1987, 1990) and in Botanical Latin, $\mathrm{k}$ and c are acceptable (Stearn, 1992).

An important fact for the present problem is that at the beginning of a word, $\rho$ is always provided with the spiritus asper or rough breathing $(\dot{\rho})$. A Greek word starting by rho transliterated into Latin must thus automatically start with rh. The same convention applies to the transliteration from classical Greek to English and French.

One should note that if transliteration is ancient, the word may have been borrowed before the stabilization of transliteration conventions during the first century A.D. (Biville, 1987, 1990). This happened with raphanus, already borrowed from Greek in Cato's time and sometime even spelled rafanus, while most classical Latin plant names in $r$ derived from Greek start with rh, like rhamnus and 17 other names (André, 1956). Names frequently used in modern times may also have evolved and changed pronunciation with the loss of the h. This occurred to rhachis, which in French and English formed rachis. Stearn (1992: 478) should not have amalgamated this case with that of raphanus and summarily conclude that retention or omission of $\mathrm{h}$ is optional. The same summary assimilation is made (p. 255) with the discussion of raphanus. The linguistically correct position is that initial rho should be transcribed rh, with, as with any orthographical rule, a few exceptions, due either to a very ancient adoption in Latin (raphanus) or recent evolution in modern languages (rachis).

Recommendation 60A of the Melbourne Code (McNeill $\&$ al., 2012) must be understood in the light of this situation. Dealing with new names it recommends using the correct rh transcription. This is not to be interpreted as forbidding correction of previous incorrect usages. Some of those incorrect usages can be accepted for the reasons explained previously, but most are correctable errors.

Since neither rhacodes, rhachodes, racodes or rachodes is reported in classical Latin, nor answer a frequent recent evolution, there is no reason to consider rachodes an established acceptable exception to correct orthography.

De Kok \& Vellinga (1998) acknowledged that "rachodes lacks a meaning" but considered it unlikely it would be a spelling mistake, Vittadini having been very consistent in this spelling. It seems those authors considered that if in a given work the author or the printer has repeated the same mistake several times, this cannot be corrected, a concept that is not part of our present Code (McNeill \& al., 2012). The text holds a typographical mistake $\rho \alpha \chi \circ \varsigma$ for $\rho \alpha \kappa o \varsigma$, which may have added to the confusion. This mistake is not due to the dictionary used

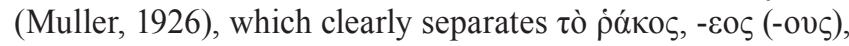

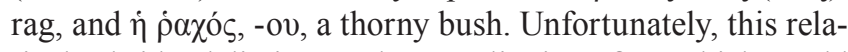
tively abridged dictionary does not list $\dot{\rho} \alpha \kappa \omega ́ \delta \eta \varsigma$, which would have made the situation clearer.

Vellinga \& Pennycook (2010a) developed a new argument, claiming that "there is no supporting evidence to be found in Vittadini's protologue" for a derivation from $\dot{\alpha \kappa \omega ́ \delta} \eta \varsigma$.
Instead they suggested the epithet could be derived from

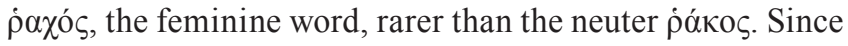
its main meaning is thorny hedge or bush the authors were led to suggest the epithet referred to the habitat of the fungus. In so doing they overlooked that the suffix -odes indicates a similarity and it needs a lot of imagination to see in this fungus a similarity to a hedge or even a bush. Further the correct transliteration of $\rho \alpha \chi o ́ \varsigma$ is rhachos as in Carnoy (1959: 229). Correction would still be needed, this time to rhachodes, which no-one ever did. Their claim that there is no direct evidence that Vittadini had meant ragged for qualifying his fungus, is contradicted by the fact the scales of the cap, its margin and the annulus are described as "lacerata", the Latin for rhacodes (Radcliffe-Smith, 1998). The ragged aspect of the margin is especially evident in fig. VIIh (misspelled IVIh in the text).

A new set of philological arguments to retain rachodes was presented to the Committee for Fungi by Melot in July

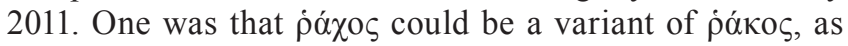
attested in the standard Greek-English dictionary of Liddell $\&$ Scott. Melot did not cite the edition he consulted, while there have been several editions of this dictionary between the first one of 1843 (that is after Vittadini's publication) and the

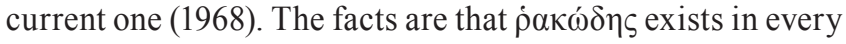
edition, with the two meanings "ragged" and "wrinkled" and

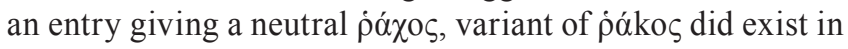
the very first editions. However, in the sixth edition of 1869 , a comment is added "dub. In Hesych." Later the authors must have been definitively convinced this was a copier's error, for the entry disappeared in the 1901 edition. Current editions of Hesychius only use pákos. As above, whether the word was feminine or neuter, it should have been transliterated rhachodes.

The classical thesaurus of Stephano (1842-1847, s.v.

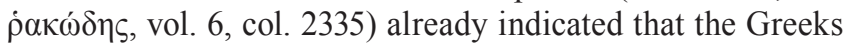
only used $\rho \alpha \kappa \omega ́ \delta \eta \varsigma$ and this is confirmed by the on-line The-

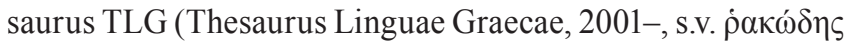
and s.v. $\rho \alpha ́ \kappa о \varsigma)$. We found 66 citations for $\rho \alpha \kappa \omega ́ \delta \eta \varsigma$ and the word $\tau$ ò $\rho$ áxo does not appear. One should be aware that in such a search, elements of words that have been cut may appear as standing alone. We did take this into consideration and checked dubious cases. Even if not very usual, $\rho \alpha \kappa \omega ́ \delta \eta \varsigma$ survives in modern Greek (Eleutheroudaki Egkiklopaidikou Lexikon, 1927-1931; Dimitrakou, 1970).

The second line of arguments of Melot refers to seventeenth century medicinal usage. Three references should show that for seventeenth century doctors, rhacodes and rachodes were two different words, applied to distinct diseases. Two authors refer to the ulcer called rachodes by the Greeks. Dalla Croce (1661; this is the edition cited by Melot, older ones which would have been more appropriate to cite, do not however differ in the spelling of rachodes) does not speak of the localization and writes "da Greci è chiamata rachodes, \& da Latini lacerosa", while Fernel (1667) in 15 pages on ulcers incidentally mentioned "... ce que les grecs appellent rhacodes qui est une tumeur naissant entre les parties honteuses". Consultation of the thesauri mentioned earlier shows that in applying rhacodes 
to an ulcer, for the Greeks, the determinant criterion was the aspect, not the localization. Dalla Croce's text was thus correct, but not his spelling. This is not surprising, for he made other errors in Latin, like using the Italian "lacerosa" instead of "lacerata". Fernel had a good spelling but an erroneously restrictive localization.

This might have come from the third work, attributed by Melot to Hilden (1682) but which is actually a text by Severino (1646) reprinted at the end of the Hilden book. In three chapters, Severino refers to an ulcer variously spelled with ra- or rha- at the beginning. Melot considered that "Cap. LXXXIVDe Racosi scroti abscessu" (this could have influenced Fernel) is to be opposed to "Caput CXXI De ulcere rachode" which starts "Est rachos graece ... ulcera quaedam inde sunt dicta rachodi quasi laciniata". However, Cap. LXXXIV uses ra- in the title and rha-in the text and Melot overlooked Cap. $C X X$, quite repetitive of Cap. $C X X I$ and where the correct spelling rhacodes is used. That Severino was confused appears in his index, where one finds "Rachos, quid?, Rhacosis, quid?", while he corrects the racosi of the title of Cap. LXXXIV to rhacosi. Things were settled in the French translation of 1668, where the correct spellings rhacodes and rhacosis are used throughout.

The truth is thus that there was not a consistent use of two spellings for two different things, but an erratic usage of $h$ after $\mathrm{r}$ in some books.

Both in the Greek and the seventeenth-century books, it appears that when applied to an ulcer, rhacodes and its misspelling rachodes designated one with a strip of skin oriented toward the middle. That is exactly the reverse from what occurs with the scales of the mushroom cap.

In conclusion, Vittadini had no reason to think of a bush, nor an ulcer, when naming his fungus. He just used an existing adjective that fitted the aspect of the cap, probably especially its lacerate margin. That he misplaced the $\mathrm{h}$ is probably some kind of dysgraphic error that is not infrequent with such words. Even one of us (V.D.) wrote rachodes, instead of rhacodes in some memos of the Committee for Fungi. Italians like Vittadini, Dalla Croce and Severino may be especially prone to that inversion for the use of $h$ in Italian is quite different from that in Latin, French or English. In that language, $h$ does not mark aspiration but is only used after $c$ and $g$ to modify their pronunciation before $e$ and $i$. This may occur in the same word, as mycologists should have noticed with fungo (pl. funghi).

Vellinga \& Pennycook (2010a) also state that transliteration is not regulated by the Code. This is only true insofar that the Code does not prescribe the use of a given standard of transliteration if several exist. For example in Rec. 46B, it just recommends to use an internationally available standard. But beside recommendations like $60 \mathrm{~A}$ and $\mathrm{E}$, the Code is very prescriptive in Art. 60.4-6 on some points of transliteration. Anyway, something that looks like a transliteration but does not answer any standard is an orthographic error. Bad transliteration may be the origin of the error, like confusion with other words in the same or different languages, it may explain but not justify the error.

Concerning the transcription of rho one will note that the correction of Diplarrena Labill. to Diplarrhena has been accepted by $I N G$ (Farr \& al., 1979) and NCU-3 (Greuter \& al., 1993), even if other authors retain the original spelling and the issue would need a discussion outside the object of this paper.

Another misinterpretation of the Code by Vellinga and Pennycook is that of the Ex. 1 to Art. 60 which states one should not change a spelling for one which is philologically preferable. "Preferable" refers to a situation where two possibilities exist, one being preferable. With rachodes one does not deal with a less preferable alternative, but an erroneous one.

One of us (V.D.) has devoted much energy to the orthography section of the Code (Demoulin 1981; Demoulin \& Nicolson 1986) and like Brummitt \& Taylor (1990) stressed Art. 60.1 exists and must be applied to blatant errors. To an unprejudiced observer it is evident rachodes is such a correctable error.

\section{口 USAGE OF THE TWO SPELLINGS}

Nowhere, when proposing to conserve an original spelling did Vellinga \& Pennycook (2010a, b) show that conserving rachodes is advantageous or stabilizing. They have to admit rhacodes is the most common form, but hope their favourite form could be imposed through conservation. This is probably the first time conservation would overrule the majority usage!

Further, the usage tables in Vellinga \& Pennycook (2010a) are not altogether accurate as demonstrated below.

In table 1, Fries (1851-1863, Lepiota: 1854) is cited; however, this is probably his only use of rachodes after 1849 and should not be emphasized since it was corrected in the 1863-supplement (p. 285) with a typographical mistake (hachodes instead of rhacodes), and fully correct in the index (p. 350, not cited in table 1).

In table 2 unrecorded uses of rhacodes are: Cooke \& Quélet (1878), Wunsche (1883), Winter (1880-1885, that is the famous Rabenhorst's Kryptogamenflora), Bommer \& Rousseau (1884) and Richon \& Roze (1888). Another major German series is lacking: Engler's Die natürlichen Pflanzenfamilien. The treatment by Hennings, who used rhacodes appeared in 1898 (Lieferungen 170, 172, 174, 181) and not in 1900 or 1907 as some bindings might make one believe. Hennings also published on South-East Asian Lepiotas in 1899, comparing his new Lepiota celebica to L. rhacodes.

In table 3 there are three English early-twentieth-century references, the four editions of Singer's Agaricales in Modern Taxonomy $(1951,1962,1975,1986)$ and recent use by authors who followed Bellù \& Lanzoni (1987, the important Bellù 1982 paper which uses rhacodes is not cited) or Vellinga. The total is of 16 uses of rachodes against 10 of rhacodes. This not only does not reflect at all the general twentieth-century literature, especially floristic, but avoids citing the authors who are at the base of the understanding of the European agaric flora. Boudier, Bresadola, Maublanc, Ricken are left aside. Lange is only cited for a 1915 paper, while his plate 25 in the Flora Agaricina Danica (1935) is one of the most cited ones in reference to that species, together with the no. 10 of Boudier (1905-1910). Romagnesi only appears through the Flore analytique (Kühner \& Romagnesi, 1953) which seems to be the only standard Flora 
for European agarics cited. The Flore monographique des amanites et des lépiotes by Quélet \& Bataille (1902) is not cited. Not only is the British checklist of Dennis \& al. (1960) not in the table, just as well than its successor (Legon \& Henrici, 2005, which is nonetheless cited elsewhere), but incredibly the most influential Flora of agarics, that of Moser, is not cited. The first edition (1953) used rhacodes, despite usual close links between Moser and Singer, and five subsequent editions and an English translation followed. If those had been recorded this would be more than the four editions of Singer's Agaricales.

The idea of table 4-showing usage outside of Europe - is displaced, for one is dealing with a European fungus, whose existence on other continents is disputable, as admitted by Vellinga (2003).

This table is limited to uses of rachodes, not even trying to present usage of rhacodes as in the other tables. Readers are thus uninformed of the frequent use of rhacodes outside Europe, including by the three founding fathers of American mycology: Peck, Farlow and Murrill. Farlow used rhacodes consistently in his 1905-index of North American fungi and when comparing it to his new Lepiota brunnea (1929). Peck, who in 1869 had used rachodes, corrected it in the index of 1888 (another omission of Table 2). The North American Flora (Murrill, 1914) is an important reference like the paper by Zeller (1933), which claims to be the first true record of Lepiota rhacodes in the U.S. Mushrooms of North America (Phillips, 1991), one of the best photographic atlases of North American fungi, uses rhacodes. Furthermore, the 1909-1966 cumulative index of Mycologia holds six references to rhacodes and none to rachodes.

An interesting case for the American literature is the paper by Helen Smith (1954) who used Lepiota racodes. This is not the correct traditional spelling, but still far more logical, in deciding not to mark the aspiration of Greek letters, than the impossible rachodes.

For Africa, the five references seen all use rhacodes (Heinemann 1970; Malençon \& Bertault, 1970; Pegler, 1977; Rammeloo \& Walleyn, 1993; Chalange, 2009). The last reference is an important work (775 pp. of supplements to the Flora of Morocco of Malençon \& Bertault), which accepts Vellinga's combination in Chlorophyllum but with the corrected rhacodes epithet.

In South America the recent Flora of Argentina by Raitelhuber (2004) uses rhacodes. For Asia, the important Flora of Kazakhstan (Samgina, 1985) uses rhacodes, like the Hong Kong checklist (Lu \& al., 2000) and it is not stated that the earlier use of rachodes by Imazeki \& Hongo had been corrected in the second edition of their iconography (1972). For Australia we have noted Shepherd \& Totterdell (1988) use rhacodes as well as the excellent Flora by Grgurinovic (1997). For New Zealand, it is easy to find from McKenzie (2004) that rhacodes was the only spelling used before Segedin \& Pennycook (2001), in particular in the first version by Segedin (1987).

Vellinga and Pennycook admit that rhacodes occurs about twice as much on the internet as rachodes and we did indeed find with Google Scholar a ratio of 2.3. Anyway those citations are limited to web accessible references. In taxonomy, the literature that is outside of electronic databases because it is old or in copyrighted books can be of great importance. If we had an exhaustive coverage of the last hundred years the ratio would be even more in favour of rhacodes.

One may also note that when a search in Google books for rachodes does not give a result, one is suggested to try rhacodes.

\section{USE OF RHACODES FOR OTHER ORGANISMS}

When reporting the majority usage of rhacodes found on the internet, Pennycook \& Vellinga (2010a) noted it also applies to plants and algae. How did those authors fail to realize that if rhacodes has been used for other organisms, this meant this was the universal correct spelling?

There are two other fungi with the epithet rhacodes: Blumenavia rhacodes A. Möller (Bras. Pilzbl.: 57. 1895) and Inocybe rhacodes J. Favre (in Ergebn. Wiss. Untersuch. Schweiz. Nationalparks, N.F., 5(33): 201. 1955) and a Lepiota subrhacodes Murrill (in Lloydia 6: 223. 1943). We did not try to trace the algae and animals, but the International Plant Name Index lists seven names of species of flowering plants (Asclepias rhacodes N.E. Br., Astragalus rhacodes Bunge, Calceolaria rhacodes Kraenzl., Dioscorea rhacodes Peter ex R. Knuth, Hieracium rhacodes Omang, Stathmostelma rhacodes K. Schum., Taraxacum rhacodes Rail.). We are unaware of the use of rachodes (or racodes) for any algal, fungal or plant taxon.

Is it reasonable to want to have a spelling for a Lepiota that is different from that used for all other organisms?

\section{CONCLUSIONS}

Until a century ago the rules on orthography were limited and correction of orthographic errors was widely admitted (Candolle 1867; Briquet, 1906). Orthography, especially Latin orthography, being less and less well known, the Code evolved toward more and more specific prescriptions. The general rule to correct orthographic errors has however been retained, with the hope it would be used with reserve (Art. 60.3). The same reserve should be expected from those who like to preserve the original spelling.

The present story is not only instructive on how orthographic matters can be time consuming, but also raises questions on the way our current committee-based system works.

Whatever their merit, proposals always seem to have an advantage on status quo. In committee discussions "the squeaking wheel gets the grease" and opposing a proposal becomes an up-hill battle. If rather than assuming rhacodes was correct and not in need of protection, a proposal to conserve Agaricus rhacodes had been made, it probably would have passed without problem, superfluous as it may have been.

Another question is whether committees for a taxonomic group should assess if a spelling is orthographically correct. This is independent of taxonomic groups, which could be an argument for referring those problems to a specific 
orthography committee, as advocated by Brummitt \& Taylor (1990). The experience of V. Demoulin (Demoulin \& Nicolson, 1986) is, however, that such a committee diverts too much energy from truly scientific tasks. It now seems that in a world where fewer and fewer people are familiar with good use of classical languages, standardization should be generalized, with conservation and voted examples for what would remain disputed cases.

The Three-language List of Radcliffe-Smith (1998) is an easy way to check existing orthographies of botanical name components. It shows that rhacodes means lacerati- in Latin, ragged or torn in English and that rachodes does not exist. If this list was ruled an official reference, no listing of rhacodes would be necessary. At the moment we would, however, prefer to see it introduced as a voted example to Art. 60.1.

Alternatively, if the reactions to this paper show it necessary the proposal to conserve rhacodes will, however, be introduced.

If the time spent on this issue is a factor helping to launch a revision of Art. 60 in the proposed direction, maybe then it was not lost.

\section{ACKNOWLEDGEMENTS}

We are grateful to Prof. Br. Rochette, Department of Ancient Studies at the University of Liège, promoter of the Master in Classical languages of L.D. and Paul Kirk, editor of Index Fungorum, for their support during the preparation of this manuscript. Gerry Moore, nomenclatural editor of Taxon, helped make the paper better centred on issues of general relevance.

\section{LITERATURE CITED}

André, J. 1956. Lexique des termes de botanique en latin. Paris: C. Klincksieck.

Bellù, F. 1982. Contributo al genere Macrolepiota Singer - $1^{\circ}$. Boll. Gruppo Micol. G. Bresadola 25: 100-121.

Bellù, F. \& Lanzoni, G. 1987. Betrachtungen über die Gattung Macrolepiota Singer in Europa. Beitr. Kenntn. Pilze Mitteleurop. 3: 189-204.

Biville, F. 1987. Graphie et prononciation des mots grecs en latin. Bibliothèque de L'Information Grammaticale 7. Louvain: Peeters.

Biville, F. 1990. Les emprunts du latin et du grec, approche phonétique. Louvain: Peeters.

Bommer, E. \& Rousseau, M. 1884. Florule mycologique des environs de Bruxelles. Gand: C. Annoot-Braecman, Ad. Hoste succ.

Boudier, E. 1905-1910. Icones mycologicae. Paris: P. Klincksieck.

Briquet, J. (ed.) 1906. Règles internationales de la nomenclature botanique adoptées par le congrès international de Vienne 1905. Jena: G. Fischer.

Brummitt, R.K. \& Taylor, N.P. 1990. To correct or not to correct? Taxon 39: 298-306. http://dx.doi.org/10.2307/1223056

Candolle, A. de 1867. Lois de la nomenclature botanique. Pp. 209-227 in: Fournier, E. (ed.), Actes du congrès international de botanique tenu à Paris en aout 1867. Paris: Germer Baillière. http://dx.doi.org/10.5962/bhl.title.11026

Carnoy, A. 1959. Dictionnaire étymologique des noms grecs de plantes. Louvain: Publications Universitaires.

Cetto, B. 1972. I funghi dal vero, 3rd ed., vol. 1. Trento: Saturnia.

Chalange, R. 2009. Révision du genre Lepiota Fr. Pp. 93-106, pl. 4-8 in: Maire, J.C., Moreau, P.A. \& Robich, G. (eds.), Compléments à la flore des champignons supérieurs du Maroc de G. Malençon et $R$. Bertault. Nice: Confédération européenne de mycologie méditerranéenne.

Cooke, M.C. \& Quélet, L. 1878. Clavis synoptica hymenomycetum europaeorum. London: Hardwicke \& Bogue.

Dalla Croce, G.A. 1661. Cirurgia universale perfecta di tutte le parte pertinenti all-oltimo Chirurgico. Venetia: Nicolo Pezzaria.

De Kok, R.P.J. \& Vellinga, E.C. 1998. Notulae ad floram agaricinam neerlandicam - XXXII Macrolepiota. Persoonia 17: 69-79.

Demoulin, V. 1981. A proposed simplification of the orthographic section of the Code of Botanical Nomenclature. Taxon 30: 233-248.

Demoulin, V. \& Nicolson, D.H. 1986. (171)-(198) Report of the special committee for orthography with proposals to amend the Code. Taxon: 794-803. http://dx.doi.org/10.2307/1221656

Dennis, R.W.G., Orton, P.D. \& Hora, F.B. 1960. New check list of British agarics and boleti. Transactions of the British Mycological Society, Suppl. to vol. 49. London: Cambridge University Press.

Dimitrakou, D. 1970. Neon Lexikon Orthographikon kai ermineutikon olis tis ellinikis Glossis. Athinai: Chr. Giobanis.

Eleutheroudaki Egkiklopaidikou Lexikon 1927-1931. Athinai: Eleutheroudaki.

Farlow, W.G. 1905. Bibliographical index of North American fungi, vol. 1(1). Washington: Carnegie Institution. http://dx.doi.org/10.5962/bhl.title.31862

Farlow, W.G. 1929. Icones farlowianae. Cambridge, Massachusetts: Farlow Herbarium.

Farr, E.R., Leussink, J.A. \& Stafleu, F.A. (eds.) 1979. Index nominum genericorum (Plantarum), vol 1. Regnum Vegetabile 100. Utrecht: Bohn, Scheltema \& Holkema; The Hague: dr. J.W. Junk.

Fernel, J. 1667. La Chirurgie. Tolose: Raymond Bosc.

Fries, E. 1849. Summa vegetabilium scandinaviae, sect. 2. Holmiae et Lipsiae: A. Bonnier.

Fries, E. 1851-1863 [“1857”, "1863”]. Monographia hymenomycetum sueciae, 2 vols. Uppsala: C.A. Leffler.

Greuter, W., Brummitt, R.K., Farr, E., Kilian, N., Kirk, P.M. \& Silva, P.C. 1993. Names in current use for extant plant genera. Regnum Vegetabile 129. Königstein: Koeltz Scientific Books.

Grgurinovic, C.A. 1997. Larger fungi of South Australia. Adelaide: The Botanic Gardens of Adelaide and State Herbarium and The Flora and Fauna of South Australia Handbook Committee.

Heinemann, P. 1970. Macrolepiota. Pp. 332-338, pl. 54-55 in: Flore iconographique des champignons du Congo, fasc. 17. Bruxelles: Jardin Botanique National de Belgique.

Hennings, P. 1898 (“1900"). Hymenomycetineae. Pp. 105-276 in: Engler, A. (ed.), Die natürlichen Pflanzenfamilien, I. Teil, Abt. 1**, Lief. 170, 172, 174, 181. Leipzig: Engelmann. http://dx.doi. org/10.5962/bhl.title.4635

Hennings, P. 1899. Fungi monsunenses. Warburg Monsunia I. Leipzig: Engelmann.

Hilden, W.F. von 1682. Opera quae extant omnia. Francofurti: I.L. Dufour.

Imazeki, R. \& Hongo, T. 1972. Coloured illustrations of fungi of Japan, 2nd ed., vol. 2. Osaka: Hoikusha. [in Japanese]

Kühner, R. \& Romagnesi, H. 1953. Flore analytique des champignons supérieurs. Paris: Masson et $\mathrm{C}^{\mathrm{ie}}$.

Lange, J.E. 1935. Flora agaricina danica, vol. 1. Copenhagen: Recato.

Legon, N.W. \& Henrici, A. (with P.J. Roberts, B.M. Spooner \& R. Watling) 2005. Checklist of the British \& Irish Basidiomycota. Kew: Royal Botanic Gardens.

Liddell, H.G. \& Scott, R. 1843. A Greek-English Lexicon. Oxford: Clarendon.

Liddell, H.G. \& Scott, R. 1869. A Greek-English Lexicon, 6th ed. Oxford: Clarendon.

Liddell, H.G. \& Scott, R. 1901. A Greek-English Lexicon, 8th ed. Oxford: Clarendon.

Liddell, H.G. \& Scott, R. 1968. A Greek-English Lexicon, compiled by H.G. Liddell and R. Scott, revised and augmented by H.S. Jones 
and R. McKenzie. Oxford: Clarendon. Reprinted with a supplement in 1996.

Lu, B., Hyde, K.D., Ho, W.H., Tsui, K.M., Taylor, J.E., Wong, K.M., Yanna \& Zhou, D. 2000. Checklist of Hong Kong Fungi. Hong Kong: Fungal Diversity Press.

Malençon, G. \& Bertault, R. 1970. Flore des champignons supérieurs $d u$ Maroc, vol. 1. Rabat: Faculté des Sciences.

McKenzie, E.H.C. (ed.) 2004. Introduction to fungi of New Zealand. Hong Kong: Fungal Diversity Press.

McNeill, J., Barrie, F.R., Buck, W.R., Demoulin, V., Greuter, W., Hawksworth, D.L., Herendeen, P.S., Knapp, S., Marhold, K., Prado, J., Prud'homme van Reine, W.F., Smith, G.F., Wiersema, J.H. \& Turland, N.J. (eds.) 2012. International Code of Nomenclature for algae, fungi, and plants (Melbourne Code). Regnum Vegetabile 154. Königstein: Koeltz Scientific Books.

Moser, M. 1953. Die Blätter- und Bauchpilze (Agaricales und Gasteromyceten). Vol. 2 of: Gams, H. (ed.), Kleine Kryptogamenflora von Mitteleuropa. Jena: G. Fischer.

Muller, F. 1926. Grieksch woordenboek, tweede druk. Groningen, The Hague: J.B. Wolter.

Murrill, W.A. 1914. Agaricaceae (pars). Pp. 1-76 in: Britton, N.L., Murrill, W.A. \& Barnhart, J.H. (eds.), North American Flora, vol. 10(1). New York: The New York Botanical Garden.

Norvell, L. 2011. Report of the Nomenclature Committee for Fungi: 18. Taxon 60: 1199-1201.

Peck, C.H. 1869. Twenty-second annual report of the Regents of the University of the State of New York on the condition of the State Cabinet of Natural History and the historical and antiquarian collection annexed thereto: Transmitted to the Legislature April 10th, 1869. Albany: The Argus Company.

Peck, C.H. 1888. Botanical index to New York State Museum reports twenty-two to thirty-eight. Pp. 94-122 in: Forty-first annual report of the Trustees of the State Museum of Natural History for the year 1887: Transmitted to the Legislature May 7, 1888. [Albany]: The Troy Press Company.

Pegler, D.N. 1977. A preliminary agaric Flora of East Africa. London: Her Majesty's Stationery Office.

Phillips, R. 1991. Mushrooms of North America. Boston: Little, Brown $\&$ Co.

Quélet, L. \& Bataille, L. 1902. Flore monographique des amanites et des lépiotes. Paris: Masson et Cie.

Radcliffe-Smith, A. 1998. Three-language list of botanical name components. Kew: Royal Botanic Gardens.

Raithelhuber, J. H. 2004. Nueva Flora micológica Argentina. Stuttgart: J.H. Raithelhuber.

Rammeloo, J. \& Walleyn, R. 1993. The edible fungi of Africa south of the Sahara: A literature survey. Scripta Botanica Belgica 5. Meise: National Botanic Garden of Belgium.

Richon, C. \& Roze, E. 1888. Atlas des champignons. Paris: Octave Doin.

Samgina, D.I. 1985. Flora sporovykh rastenij Kazakhstana, vol. 13(2), Agarikovye griby / Agaricales. Alma Ata: Akademiya Nauk.

Segedin, B.P. 1987. An annotated checklist of agarics and boleti recorded from New Zealand. New Zealand J. Bot. 25: 185-215. http://dx.doi.org/10.1080/0028825X.1987.10410067
Segedin, B.P. \& Pennycook, S.R. 2001. A nomenclatural checklist of agarics, boletes, and related secotioid and gasteromycetous fungi recorded from New Zealand. New Zealand J. Bot. 39: 285-348. http://dx.doi.org/10.1080/0028825X.2001.9512739

Severino, M.A. 1646. De efficaci medicina Libri III. Francofurti: Ap. Joannem Beyerum.

Severin[o], M.A. 1668. De la médecine efficace. Genève: Pierre Chouët.

Severino, M.A. 1682. De efficaci medicina Libri III. Francofurti. I.L. Du Four.

Shepherd, C.J. \& Totterdell, C.J. 1988. Mushrooms and toadstools of Australia. Melbourne: Inkota.

Singer, R. 1951 ["1949"]. The "Agaricales" (mushrooms) in modern taxonomy. Lilloa 22: 1-832.

Singer, R. 1962. The Agaricales in modern taxonomy, 2nd ed. Weinheim: J. Cramer.

Singer, R. 1975. The Agaricales in modern taxonomy, 3rd ed. Vaduz: J. Cramer.

Singer, R. 1986. The Agaricales in modern taxonomy, 4th ed. Königstein: Koeltz Scientific Books.

Smith, H.V. 1954. A revision of the Michigan species of Lepiota. Lloydia 17: $307-328$.

Stearn, W.T. 1992. Botanical Latin, 4th ed. Newton Abbot, Devon: David \& Charles.

Stephano, H. 1842-1847. Thesaurus Graecae Linguae. Paris: Didot.

Thesaurus Linguae Graecae 2001-. stephanus.tlg.uci.edu/inst/text search (accessed 6 Feb. 2012).

Vellinga, E.C. 2003. Chlorophyllum and Macrolepiota (Agaricaceae) in Australia. Austral. Syst. Bot. 16: 361-370. http://dx.doi.org/10.1071/SB02013

Vellinga, E.C. (with coll. of R.P.J. de Kok) 2001. Macrolepiota Sing. Pp. 64-73 in: Noordeloos, M.E., Kuyper, T.W. \& Vellinga, E.C. (eds.), Flora Agaricina Neerlandica, vol. 5. Lisse: A.A. Balkema.

Vellinga, E.C. \& Pennycook, S.R. 2010a. Making a case for the original spelling of an epithet: 'correction' of the original spelling of Agaricus rachodes to Agaricus rhacodes (Basidiomycota) is unjustified. Taxon 59: 623-627.

Vellinga, E.C. \& Pennycook, S.R. 2010b. (1927) Proposal to conserve the name Agaricus rachodes (Basidiomycota) with that spelling. Taxon 59: 644.

Verbrugghe, G.P. 1999. Transliteration or transcription of Greek. Classical World 92: 499-511. http://dx.doi.org/10.2307/4352343

Vittadini, C. 1832-1835 [“1835”]. Descrizione dei funghi mangerecci, fasc. 4-6 (pp. 65-164: 1833). Milano: F. Rusconi. http://dx.doi.org/10.5962/bhl.title.63260

Winter, G. 1880-1885 ["1884"]. Die Pilze Deutschlands, Oesterreichs und der Schweiz, 1. Abth., Schizomyceten, Saccharomyceten und Basidiomyceten $=$ Dr. L. Rabenhorst's Kryptogamen-Flora von Deutschland, Oesterreich und der Schweiz, 2nd ed., vol. 1, Pilze (Lief. 13, pp. 833-870: 1883). Leipzig: Eduard Kummer. http://dx.doi.org/10.5962/bhl.title.1356

Wunsche, O. 1883. Flore générale des champignons. Paris: O. Doin.

Zeller, S.M. 1933. New or noteworthy agarics from Oregon. Mycologia 25: 376-391. http://dx.doi.org/10.2307/3754013 